\title{
NARRATIVES OF IDENTITY
}

\author{
Saami identity in the Swedish cultural memory
}

\section{Amanda Björkman}

\begin{abstract}
Sweden portrays itself as a champion of human rights. Simultaneously, it violates the rights of its indigenous Saami population. To understand the dynamics of this duplicity, this interdisciplinary study explores how Saami identity is constructed and perceived in Swedish cultural memory. Avril Bell's (2014) theory of the settler imaginary is applied to analyse the narrative on Saami identity in Swedish school textbooks, legislation, political debates, and its historical context. The findings indicate that Saami identity, in Swedish cultural memory, has been constructed by Swedish settlers as authentic, static and incompatible with the majority of society. This image is perpetuated in the present day's educational and political institutions. Implications of such an image are reflected in discrimination against the Saami.
\end{abstract}

\section{Introduction}

Sweden has, since the end of the Second World War, portrayed itself as a protector of human rights and at the frontline of equality. This endeavour has resulted in the construction of both a national and global image of Sweden as devoid of a 
colonial past (MacEachrane, 2018). Contrary to this image, Sweden's history tells a story of colonisation and exploitation of the Swedish indigenous population, the Saami. At the same time as UN reports on the continuous violations of the Saami's rights by the Swedish state (United Nations Human Rights Committee, 2016), several voices have begun to warn of a lack of knowledge among the majority population in Sweden regarding their indigenous population (Asplund, 2015; Hällgren, 2017; Utbildningsradion, 2018). The ignorance that seems to prevail among the Swedish majority is the point of departure for this essay, particularly considering the relatively few academic accounts covering this topic.

The exploitation of Sápmi - the land of the Saami - began in the $14^{\text {th }}$ century under the Swedish crown. Thenceforth, an asymmetrical relationship between the Saami and the Swedish majority society has persisted. Although it has been altered and modified, the structure remains the same - a continuous disregard for Saami agency in the construction of Saami history and identity in the Swedish cultural memory. Cultural memory is a collective understanding, or agreement, on knowledge that influences actions, views and beliefs (Assmann \& Czaplicka, 1995). The cultural memory of a society is established and maintained through societal and institutional practices. Along these lines, this paper addresses the following question: How is Saami identity constructed and perceived in Swedish cultural memory?

To answer the research question, this essay employs Avril Bell's (2014) concept of the settler imaginary as a theoretical framework, which is elaborated on in the first section of the essay. An examination of the historical construction of Saami identity in Swedish cultural memory follows. The analysis further considers how the conception of the Saami is reproduced in Swedish educational, political and legal institutions. Thus, an interdisciplinary framework is utilised, situating the essay primarily in memory studies, but also drawing upon history, identity studies, and politics. The interdisciplinary approach is used to enable a profound understanding of the dynamics of the construction of Saami identity. Beyond the interdisciplinarity of this paper, its focal point has relevance for other fields of study. It can be explored in relation to law, both international and national. Saami identity construction entails dimensions of Saami rights, which are of various degrees in the different countries the Saami reside in. Moreover, the construction of Saami identity can also be situated in the study of social movements. The Saami struggle for autonomy has a collective nature, spanning across all nations the Saami reside in (Sametinget, 2019). The demand for autonomy is often framed as intertwined with representation and visibility, which are gained through protests and resistance practiced by many Saami, and is thus linked to the topic this paper deals with. 
Ultimately, this essay argues that Saami identity, in Swedish cultural memory, has been constructed by Swedish settlers as authentic, static and incompatible with the majority society. This image is perpetuated in the present day's educational, political and legal institutions, which treat the Saami as uniform. The essay refers to the non-Saami Swedes as either settlers or the Swedish majority society. Saami are referred to as indigenes, natives, or simply Saami. This is done to facilitate the distinction between the two groups in the analysis.

\section{Theoretical framework}

To examine the conception of the Saami in Swedish cultural memory, Bell's (2014) concept of the settler imaginary is applied as a theoretical framework. Bell defines the settler imaginary as "the set of ideas and values that underpin a peculiarly settler discourse of nationhood, identity and indigenous-settler relations" (p. 11). In other words, the settler imaginary considers how settlers establish narratives of national identity and indigenous identity, which come to define the image of indigeneity in Swedish cultural memory. The settler imaginary has its roots in primitivist and racist conceptions that are used to justify colonialism (p. 18).

Authenticity is an important component of the settler imaginary. It is a trait attributed to the indigenous group by the settlers, that portrays the indigenous as traditionalist and static. As the settlers view themselves as modern and dynamic, a dualism is created pointing to an incompatibility between the culture of the settler and the culture of the indigene. Indigenous culture is considered as opposite and irreconcilable with modern ways, and "not appropriate to the management of economic life, the organisation of social relationships, or the practice of government" (Bell, 2014, p. 4). This perception consequently functions as a justification for the settlers to expropriate the agency and right to autonomy of the indigenes. However, Bell (2014) states that the authenticity ascribed to the natives "has been simultaneously viewed as a state of purity and innocence and as one of brutishness" (p. 28). The paradoxical nature of authenticity suggests that it is externally attributed.

The projection of authenticity onto indigenous people has consequences for their rights and self-determination. Cultural memory generates expectations among the majority society on the indigenes. If the natives adhere to the characteristics of authenticity, they are granted rights and political representation (Bell, 2014, pp. 55-56). Those who fail to satisfy the ascribed attributes, however, are considered as deviant, and are either assimilated - deprived of their indige- 
nous status and identity - or demonised (p. 48). Ultimately, although Bell (2014) has established her theory primarily through research conducted on indigenous groups in New Zealand, Australia, Canada and the United States, it provides a framework from which Saami identity can be analysed, due to similar structures of colonialism and exploitation between the Swedish Sápmi and the nations analysed by Bell.

To examine the depiction of Saami using the lens of Bell's (2014) theory, this study consults secondary literature on Saami representation in school books, legislation and political discussions. The findings of these studies are consequently analysed under the framework of the settler imaginary. To understand the collective conception of the Swedish majority society's view on the Saami, the research must address the Swedish population as a whole. Following this pursuit, the analysis constitutes the examination of how Saami are represented in Swedish school textbooks - the fundamental and often first contact with the Saami for the majority of Swedish people. The analysis focuses on the compulsory school years, age 6-16, and the social sciences textbooks used for these years. Firstly, the curriculum for the compulsory education, published by the national educational institution of Skolverket (2018), is analysed to examine what image, if any, the state attempts to put across of the Saami. Thereafter, secondary literature is consulted for an examination of the actual depiction of Saami in textbooks. This paper elaborates on the extensive collection of data regarding Saami appearance in Swedish social science textbooks conducted by Karlsson (2004), Runblom (2006), Pikkarainen and Brodin (2008a; 2008b), and Åström Elmersjö (2017).

The Swedish state substantially influences the portrayal of the Saami, also through institutions other than education. Therefore, to ensure a more comprehensive view of the state sanctioned depiction of Saami in the Swedish cultural memory, the analysis incorporates an examination of how the Saami are portrayed in legislation and political debates. Primarily, this paper focuses on the Reindeer Grazing Act of 1971, a crucial legislation influencing Saami livelihood, and the account of Nyström (2018) on how Swedish politicians refer to Saami people and Sápmi. Before the analysis of the contemporary depiction of Saami can commence, however, it is of interest to consider the narrative on Saami from a historical perspective. This enables the findings to be contextualised, facilitating the understanding of why Saami identity is depicted in a certain way - and to what extent this depiction is generated by the settler imaginary. 


\section{Analysis}

\section{I The construction of Saami identity throughout history}

The Saami live in an area called Sápmi, which spans across Norway, Sweden, Finland and Russia. There are approximately 35.000 Saami in Sweden ("Samerna i Sverige [The Sámi in Sweden]", 2016) - a number widely contested, as Sweden does not conduct demographic statistics on an ethnic basis. Although the relation between the Swedish majority society and the Saami date far back, the Swedish solidification of political, economic and social control of the Swedish Sápmi began first in the $17^{\text {th }}$ century, by means of colonisation and Christian missionisation (Lehtola, 2015). The initial approach to social control in Sápmi was assimilation. Saami children were put in special schools, where the aim was to teach them the values and beliefs of the majority society (Pikkarainen $\&$ Brodin, 2008a). The assimilation was one attempt to deal with the spatial and alleged cultural separation between Saami and the Swedish majority society, by simply disregarding Saami customs.

In the $19^{\text {th }}$ century, the approach of assimilation was superseded following the ascendancy of social Darwinism. The majority society in Sweden began to view themselves as more civilised and developed than the Saami (Fur, 2008). The racial thinking did not merely accentuate the already existing division between Swedes and Saami; it fostered a sentiment among the majority that Saami should remain Saami, and that "the exposure of the Saami to civilisation through education, residential housing, and other means should be limited as they by nature were unfit for it" (McEachrane, 2018, p. 477). Saami children were placed in special nomad schools, separated from other Swedish children. In 1921, the state institution for race biology and eugenics was established in Sweden - a direct manifest of the fixation with race and social categorisation. The publications of the institute defined the Saami as "the most inferior of white Europeans" (McEachrane, 2018, p. 478). Thus, as suggested by Bell (2014), the professed difference between Saami and other Swedes was rooted in racial conceptions.

The sentiments of the $19^{\text {th }}$ and $20^{\text {th }}$ centuries also had social and economic consequences. Lundmark (2006) discusses how the focus on social categorisation instigated the perception that settled farming, widespread in the majority society, was more developed and civilised than the nomadic culture traditionally ascribed to the Saami. These conceptions justified the claims the state made on Sápmi land - under the control of the government the land could be used for "something more purposeful" (Lundmark, 2006, p. 9) - and were both rooted in and perpetuated the idea the Saami must remain separated from the Swedish 
society. Thus, the portrayal of Saami culture as incompatible with the majority culture was present in several societal domains.

In the aftermath of the Second World War, the approach of the Swedish majority society toward the Saami began to thaw. Sweden recognised the Saami as an indigenous group in 1977. This acknowledgement meant that the Saami were granted special rights in terms of self-determination, land and water (Pikkarainen \& Brodin, 2008a). However, Sweden has not ratified the International Labour Organisation's Convention 169, which aims to specify and protect the rights of indigenous people worldwide (Lantto \& Mörkenstam, 2008). It is a crucial convention for the protection of indigenous rights. Thus, Sweden's unwillingness to ratify it suggests the persistence of the asymmetrical relationship between the Saami and the Swedish state, rooted in the settler imaginary. It is manifest in the reluctance to grant Saami autonomy to determine their culture, identity and socioeconomic needs.

Having analysed the historical context of Saami identity in Swedish cultural memory, it is of interest to point out that the research on Saami - consisting of relatively few accounts - stem mainly from non-Saami sources. Lundmark (2006) states that the historical accounts incorporating the Saami in Swedish cultural memory only emerged as the Swedish nation state expanded into Sápmi. This is a manifest of the settler imaginary; few attempts have been made to investigate the independent Saami history as it is considered static and unimportant. Although a more profound examination of these tendencies is outside the scope of this paper, it highlights the tradition the disregard a Saami perspective in the telling of the Swedish national history.

\subsection{The depiction of Saami in Swedish schoolbooks}

The disregard for a Saami perspective is present also in the Swedish institution of education. Prior to the 1990s, few Swedish school textbooks incorporated accounts of the indigenous Saami (Åström Elmersjö, 2017, p. 268). Since then, however, demands for such knowledge are integrated in the national school curriculum in Sweden. Skolverket (2018) - the Swedish national agency for education - states that it aims for each student, upon completion of the compulsory school years, to have "obtained knowledge about the cultures, languages, religion and history of the national minorities" (p. 12). In the curricula for the social sciences - civics, history, geography, and religion - Skolverket elaborates on what knowledge on the indigenous population they deem important. In the history curriculum, knowledge regarding the "[h]istorical perspective on indigenous Sami" (p. 213) is emphasised. In the curriculum for religion, Skolverket stresses "[n]arratives from ancient Scandinavian and the older Sami religion" (p. 220). 
Lastly, in civics, Skolverket's curriculum considers "[t]he indigenous Sami people and other national minorities in Sweden. The national minorities' rights" (p. 230), as well as "[t]he national minorities and the Sami status as an indigenous people in Sweden and what their special position and rights mean" (p. 231). Although information about the Saami is explicitly demanded by Skolverket, what exactly this information should entail remains vague and open for interpretation.

Karlsson (2004) observes that few schoolbooks fulfil the criteria of Saami representation in education. In Karlsson's extensive analysis of 63 social science textbooks used for the compulsory school years, only 33 gave any account of the Saami, and the depictions were often sporadic and stereotypical. A similar study by Runblom (2006) on the representation of ethnic minorities in eighteen Swedish schoolbooks resonates with Karlsson's findings. Of the six civics textbooks analysed, only one - SOL 3000: Samhälle i dag 7-9 [SOL 3000: Society today 7-9] - fulfils the curriculum criteria and gives a profound and nuanced depiction of the Saami (Runblom, 2006, pp. 36-37; 46). The book explains the Saami as an indigenous group and discusses colonisation and coercion conducted by the Swedish state. However, this textbook also contains elements of discrimination. It distinguishes between the Saami and the majority society - the latter is referred to as "Swedish speaking [own translation]" (Runblom, 2006 p. 37). This neglects the fact that the Saami also speak Swedish and thus reinforces the conceived distinction between the two. It also suggests links to the settler imaginary: as Swedish is conceived as the language of the civilised majority society, the conceptualisation of Saami as less civilised and developed generates the perception that they do not speak Swedish.

The remaining textbooks in Runbloms' (2006) study give, similarly to Karlsson's (2004) findings, simple and trivial depictions of the Saami. The civics book samhälle.nu, for instance, states that the Saami are well respected in today's society (as cited in Runblom, 2006, p. 39), without offering further nuances. This is not solely a bold claim; it is inaccurate. The Swedish institution against discrimination - the Equality Ombudsman - stresses the presence of discrimination toward Saami in the Swedish society (Pikkarainen \& Brodin, 2008a). Ultimately, most schoolbooks follow the same pattern: if they mention the Saami, the sections are typically too brief to go in depth or fail to nuance the information presented (Runblom, 2006; Karlsson, 2004). Although the textbooks for religion are more extensive in their account of the indigenous population, they also fail to establish an elaborate picture as they primarily apply a historical perspective (Runblom, 2006, p. 46). Thus, they disregard parallels between the past and the present. Yet again, this can be located in the tradition of the settler imag- 
inary. As Saami are considered as static, there is perceived to be no change in their culture or identity over time.

The findings of Pikkarainen and Brodin (2008b), reporting on behalf of the Equality Ombudsman, bear great resemblances with Karlsson (2004) and Runblom's (2006) results. Pikkarainen and Brodin have analysed textbooks for history and civics used in Swedish compulsory education. According to their report, the schoolbooks are inadequate in their examination of the Saami's situation, and fail to address the relationship between the Saami and the Swedish state thoroughly. The texts also have tendencies of discrimination in their portrayals. In interviews, some Saami state that the education does not strengthen their identity or culture, which is an explicit aim of Skolverket (Pikkarainen \& Brodin, 2008a). Rather, the information in the schoolbooks only reinforce the stereotypical depiction of the indigenous group and tend to regard the Saami as a subject of Swedish national history (Åström Elmersjö, 2017, p. 268). Ultimately, although the Swedish national curriculum emphasises historical, religious, cultural, and societal discussions regarding the indigenous Saami, the actual school textbooks, if anything, merely touch upon a few of these aspects.

\subsection{Portrayal of Saami in legislation and political debates}

The most important legislation in Sweden with regard to the Saami is the Reindeer Grazing Act of 1971 (Rennäringslag, 1971). The act stresses the Saami's economic and cultural connection to reindeer herding. However, in doing so, it also adheres to the settler imaginary. Lantto and Mörkenstam (2008) state that the aim of the Reindeer Grazing Act is to "spatially separate two different forms of activity pursued in the north of Sweden - reindeer herding and farming" (p. 29). To make the two compatible and allow for the spread of agriculture, the act emphasises reindeer herding as the core of Saami culture and economy, and a nomadic culture as essential to proper reindeer husbandry. Thus, a narrative of the authentic Saami as nomadic reindeer herder is institutionalised in Swedish law.

It is through the Reindeer Grazing Act that "the Swedish Saami find practical land-based recognition in Swedish law" (Beach, 2007, p. 5). The legislation has constructed economic communities - called Sameby - which have been granted territorial rights for reindeer herding, excluding other economic livelihoods (Rennäringslag, 1971). Saami committed to other means of subsistence have, consequently, been denied their land claims. The territorial prerogatives are a means "to preserve the unique Saami culture" (Beach, 2007, p. 5). Or rather to maintain the image of the authentic Saami in cultural memory. As postulated by Karppi and Eriksson (2002) this policy has created a dyad between Swedish and the authentic Saami, in which one cannot belong to both. The Saami herder, 
due to the special privileges granted in the Reindeer Grazing Act, is constructed and institutionalised as the 'real' Saami. The indigenes who do not replicate the majority society's definition of Saami are consequently deprived of their Saami identity. Ultimately, this is problematic, as merely 10-15 percent of the Saami population are reindeer herders (Beach, 2007). Thus, the depiction of the indigenous Saami in Swedish cultural memory excludes many Saami in terms of territory, but also in the practice of identity and culture.

Furthermore, other political domains also encompass the narrative of the 'real' Saami. Nyström (2018) analyses parliamentary debates conducted in Sweden between 2010 and 2015. In the debates, the politicians refer to Sápmi as "reindeer-herding territory" (Nyström, 2018, p. 40). The emphasis on reindeer herding perpetuates the authentic delineation of Saami reflected in the Reindeer Grazing Act. Another relevant aspect reported by Nyström (2018) is how the political discourse tend to "regard Sami rights to land and water as a privilege given by a kind Swedish state" (p. 43), although the territory historically belonged to the Saami. The framing of territory present in the political realm suggests that Sweden has benevolently given the land to those in need. Such a discourse adheres to the theoretical framework, as it portrays the Saami as subordinate to, and dependent on, the Swedish majority society. It also supports the global image of Sweden without a colonial past; Sweden has given its northern territories to the Saami, not forcefully taken them. Moreover, the narrative suggests that Saami survive because the Swedish state protects them. Again, a manifestation of the authenticity attributed to the Saami - a relic that must be preserved.

\section{Discussion and conclusion}

The analysis of Swedish schoolbooks, legislation, and political narratives manifest a consistent trend to treat the Saami as, and reduce them to, a homogenous unit. This unit is characterised as the authentic and nomadic reindeer herder. In the school textbooks, the depictions are rudimentary and fail to offer a nuanced interpretation of the Saami. The Reindeer Grazing Act perpetuates the authentic image, granting reindeer herding Saami territorial privileges. Political leaders demonstrate ignorance, or perhaps a certain political agenda, as they too delineate Saami as reindeer herders. The reproduction of this image in political and educational domains, leads to institutionalisation, which is an integral component of the formation of a cultural memory (Assmann \& Czaplicka, 1995). Thus, a collective narrative of the authentic and static indigene has formed and is main- 
tained by Swedish institutions. The settler imaginary - in other words - is firmly anchored in the Swedish cultural memory.

Although the reality of Saami culture and history contests the narrative of the authentic Saami identity, reindeer herding is the distinctive, if not only, characteristic of the Saami in Swedish cultural memory. Thus, a discrepancy exists between the cultural memory that forms the collective understanding of the Saami, and the actuality of Saami life and culture. The tenacity of the authentic narrative can partly be explained by the historical context. The image of the authentic Saami has been deeply ingrained in the minds of the Swedish majority society since the early $19^{\text {th }}$ century. Also prior to that, the relationship was asymmetrical, and the Saami considered as different and inferior to the Swedish majority. This suggests the unvarying prospect of this image - it is ingrained in the mindset of a whole nation. Ultimately, as the discussion shows, the findings of this essay conclude that Saami identity, in Swedish cultural memory, has been constructed by Swedish settlers as authentic, static and incompatible with the majority society. This image is perpetuated in the present day's educational, political and legal institutions, which treat the Saami as uniform.

The persistence of the image of the authentic Saami underpins the importance of the findings in this paper. The depiction in educational and political institutions do little but reinforce the dominant narrative of Saami identity, despite the national curriculum stressing a more comprehensive discussion on the Saami. Moreover, this narrative has political, economic and social consequences for the Swedish indigenous group. To delve into such consequences is beyond the scope of this paper. However, their sole existence is important to highlight, as it gives this study a relevance that transcends the mere failure of school textbooks to fulfil the criteria of the national curriculum. The violations of Saami rights reported by the UN, the Equality Ombudsman's report on discrimination toward the Saami, and the global image of Sweden as devoid of a colonial past, are three such consequences, resulting from a neglect of Saami autonomy in defining themselves in the Swedish cultural memory.

Due to a limited scope, the essay mainly consults secondary literature, with the exceptions of the national curriculum of the Swedish compulsory education and the Reindeer Grazing Act. Thus, the primary analysis relies on other scholars' interpretations. Whilst a limitation for this paper, it also suggests an area for further research - to expand the study to include a more comprehensive discussion on primary sources. Furthermore, to induce a change in the portrayal of the Saami, it would be of interest for further research to attempt to frame the history of settler-indigenous relations based on the memory and narrative of Saami people. This would not solely ensure a more nuanced and profound depiction of the 
history of Sweden as a whole, but it would also act to restore the deprived agency of Saami in defining their own history and identity in the Swedish cultural memory. Only then will the global image of Sweden as egalitarian and an advocate of human rights fully align with reality.

\section{References}

Asplund, R. (2015, November 16). Stor okunskap om hur kyrkan förtryckt samerna [Great lack of knowledge of how the church has oppressed the Sámi]. Retrieved from https://www.minoritet. se/3879

Åström Elmersjö, H. (2017). En av staten godkänd historia [A history approved by the state]. Lund: Nordic Academic Press.

Assmann, J., \& Czaplicka, J. (1995). Collective memory and cultural identity. New German Critique, 65, 125-133. doi:10.2307/488538

Beach, H. (2007). Self-determining the self: Aspects of Saami identity management in Sweden. Acta Borealia, 24(1), 1-25. doi:10.1080/08003830701411605

Bell, A. (2014). Relating indigenous and settler identities: Beyond domination. Hampshire: Palgrave Macmillan.

Fur, G. (2008). Tillhör samerna den svenska historien [Do the Sámi belong to the Swedish history]? HumaNetten, 22, 1-10. Retrieved from http://urn.kb.se/resolve?urn=urn:nbn:se:lnu:diva-33276

Hällgren, K. (2017, March 2). Nu räcker det med okunskap om samer [The ignorance of the Sámi is enough]. Sveriges Radio. Retrieved from https://sverigesradio.se/sida/artikel. aspx? programid $=2327 \&$ artikel $=6643604$

Karlsson, T. (2004). Exotiska renskötare och trolltrummans magi: samer och samiska frågor i grundskolans läromedel för de samhällsorienterande ämnena [Exotic reindeer herders and magic drums: Saami and Saami issues in the compulsory school's teaching materials for social science-oriented subjects]. Umeå: Umeå University.

Karppi, K., \& Eriksson, J. (2002). Conflict and cooperation in the North. Umeå: Norrlands Universitetsförlag.

Lantto, P., \& Mörkenstam, U. (2008). Sami rights and Sami challenges. Scandinavian Journal of History, 33(1), 26-51. doi:10.1080/03468750701431222

Lehtola, V.-P. (2015). Sámi histories, colonialism, and Finland. Arctic Anthropology, 52(2), 22-32.

Retrieved from https://muse.jhu.edu/article/612132\#info_wrap

Lundmark, L. (2006, November 29). När makten tappade minnet: De dunkla decennierna i början av 1800-talet. Lecture presented at the Makt och Minne [Power and Memory] Conference in Östersund. Retrieved from http://www.lennartlundmark.se/web/artiklar

McEachrane, M. (2018). Universal human rights and the coloniality of race in Sweden. Human Rights Review, 19(4), 471-493. doi:10.1007/s12142-018-0510-x 
Nyström, M. (2018). Narratives of truth: An exploration of narrative theory as a tool in decolonising research. In G. Roche, H. Maruyama, \& $\AA$. V. Kroik (Eds.), Indigenous efflorescence: Beyond revitalisation in Sapmi and Ainu Mosir (pp. 29-52). Australia: ANU Press.

Pikkarainen, H., \& Brodin, B. (2008a). Discrimination of the Sami - the rights of the Sami from a discrimination perspective (Report number 2008:1). Retrieved from http://www.do.se/ om-diskriminering/publikationer/

Pikkarainen, H., \& Brodin, B. (2008b). Diskriminering av nationella minoriteter inom utbildningsväsendet [Discrimination of national minorities in education] (Report number 2008:2). Retrieved from http://www.do.se/om-diskriminering/publikationer/

Rennäringslag [Reindeer Grazing Act], SFS 1971:437, Sveriges Riksdag (1971 \& Supp. 2018). Retrieved from https://www.riksdagen.se/sv/dokument-lagar/dokument/svenskforfattningssamling/rennaringslag-1971437_sfs-1971-437

Runblom, H. (2006). En granskning av hur etnisk tillhörighet framställs i ett urval av läroböcker: Underlagsrapport till Skolverkets rapport "I enlighet med skolans värdegrund?" [An examination of how ethnic affiliation is portrayed in a selection of textbooks: Report to the Swedish National Agency for Education's report "In accordance with the school's core values?"] (285). Retrieved from https://www. skolverket.se/publikationer?id=1659

Samerna i Sverige [The Sámi in Sweden]. (2016, May 11). Retrieved from https://www.sametinget. se/samer

Sametinget [The Sami Parliament]. (2016, May 2). Sami self-determination. Retrieved from https:// www.sametinget.se/10169

Skolverket [Swedish National Agency for Education]. (2018). Curriculum for the compulsory school, preschool class and school-age educare. Retrieved from https://www.skolverket.se/andra-sprakother-languages/english-engelska

United Nations Human Rights Committee. (2016). Concluding observations on the seventh periodic report of Sweden (CCPR/C/SWE/7). Retrieved from https://www.ohchr.org/EN/Countries/ ENACARegion/Pages/SEIndex.aspx

Utbildningsradion [Swedish Educational Broadcasting Company]. (2018, March 15). Ny Novusundersökning: mycket låg kunskap om Sveriges nationella minoriteter [New Novus survey: very little knowledge about Sweden's national minorities]. Retrieved from https://www.ur.se/press\#/ pressreleases/tag/novus 